Research paper

\title{
Characterization of vasa homolog in a neotropical catfish, Jundiá (Rhamdia quelen): Molecular cloning and expression analysis during embryonic and larval development
}

\author{
Juliana M.B. Ricci ${ }^{\mathrm{a}, 1}$, Emanuel R.M. Martinez ${ }^{\mathrm{a}, 1}$, Arno J. Butzge ${ }^{\mathrm{a}}$, Lucas B. Doretto ${ }^{\mathrm{a}}$, \\ Marcos A. Oliveira ${ }^{\mathrm{a}}$, Robie Allan Bombardelli ${ }^{\mathrm{b}}$, Jan Bogerd ${ }^{\mathrm{c}}$, Rafael H. Nóbrega ${ }^{\mathrm{a}, *}$

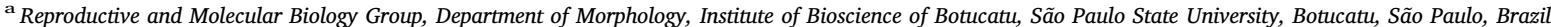 \\ b Center of Engineering and Exact Sciences, Universidade Estadual do Oeste do Paraná, Rua da Faculdade 645, 85903-000 Toledo, PR, Brazil \\ ${ }^{\mathrm{c}}$ Reproductive Biology Group, Division Developmental Biology, Department of Biology, Faculty of Sciences, Utrecht University, Hugo R. Kruyt Building, Padualaan 8, 3584, \\ $\mathrm{CH}$, Utrecht, The Netherlands
}

\section{A R T I C L E I N F O}

\section{Keywords:}

vasa

Teleost

Primordial germ cell

Germ cell

\begin{abstract}
A B S T R A C T
We have characterized the full-length vasa cDNA from Jundiá, Rhamdia quelen (Heptapteridae, Siluriformes). vasa encodes a member of the DEAD-box protein family of ATP-dependent RNA helicases. This protein is highly conserved among different organisms and its role is associated with RNA metabolism. In the majority of the investigated species, vasa is restricted to the germ cell lineage and its expression has been used to study germline development in many organisms, including fish. The deduced $R$. quelen vasa amino acid sequence displayed high similarity with Vasa protein sequences from other organisms, and did not cluster with PL10 or P68 DEAD-box protein subfamilies. We also reported that there is no other isoform for vasa mRNA in $R$. quelen gonads. Expression analysis by RT-PCR and qPCR showed vasa transcripts exclusively expressed in the germ cells of $R$. quelen gonads. $R$. quelen vasa mRNA was maternally inherited, and was detected in the migrating primordial germ cells (PGCs) until $264 \mathrm{~h}$ post-fertilization during embryonic and larval development. This work has characterized for the first time the full-length $R$. quelen vasa cDNA, and describes its expression patterns during $R$. quelen embryonic and larval development. Our results will contribute to the basic reproductive biology of this native species, and will support studies using vasa as a germ cell marker in different biotechnological studies, such as germ cell transplantation.
\end{abstract}

\section{Introduction}

vasa encodes a member of the DEAD (Asp-Glu-Ala-Asp) box protein family of ATP-dependent RNA helicase (Linder et al., 1989; Rocak and Linder, 2004). DEAD-box proteins comprised three subfamilies: VASA, PL10, and P68. The vasa gene was thought to arise from the duplication of a PL10-related gene prior to the appearance of sponges, but following the diversion of fungi and plants (Mochizuki et al., 2001). It belongs to a complex of RNAs and proteins required for primordial germ cell (PGC) specification, and was first identified in the germ plasm of Drosophila eggs (see Nakamura and Seydoux, 2008). Among the transcripts involved in PGC specification, vasa is one of the most conserved across evolution, and consequently the most studied universal marker and regulator of germ cell development (Lasko and Ashburner, 1988; Ikenishi and Tanaka, 1997; Kuznicki et al., 2000; Tsunekawa et al., 2000; Hickford et al., 2011; Hartung et al., 2014; Reitzel et al., 2016). In this context, vasa homologs have been characterized in many organisms as a specific germ line transcript (Saffman and Lasko, 1999; Raz, 2003), such as in fish, e.g. Danio rerio (Yoon et al., 1997), Dicentrarchus labrax (Blazquez et al., 2011), Gadus morhua L. (Presslauer et al., 2012), Salmo salar (Nagasawa et al., 2013), Carassius auratus gibelio (Xu et al., 2005), Clarias gariepinus (Raghuveer and Senthilkumaran, 2010), Apostichopus japonicus (Yan et al., 2013) and Lates calcarifer (Xu et al., 2014). Moreover, recent studies have shown that vasa is crucial for germ cell development. In invertebrates, $D$. melanogaster females with vasa (vas) alleles mutation showed different

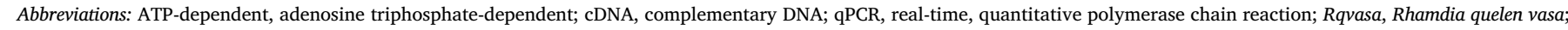

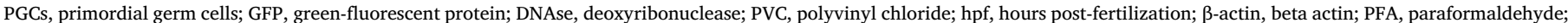

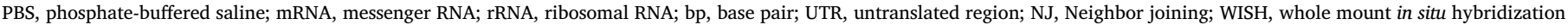

* Corresponding author at: UNESP - Campus de Botucatu, Instituto de Biociências, Rua Prof. Dr. Antonio Celso Wagner Zanin, s/nº, 18618-689 Botucatu, Brazil.

E-mail address: nobregarh@ibb.unesp.br (R.H. Nóbrega).

${ }^{1}$ These authors contributed equally to this work. 
defects on oogenesis and infertility (Schupbach and Wieschaus, 1991). In mice, targeted mutation of vasa $(M v h)$ caused reproductive deficiency in proliferation and differentiation of male germ cell (Tanaka et al., 2000). In the teleost fish medaka (Oryzias latipes), vasa knockdown led to defects in PGC migration but did not alter their number, identity, proliferation and motility (Li et al., 2009). In zebrafish, disruption of vasa resulted in sterility, but only for males (Hartung et al., 2014).

Recent studies have established transgenic lines that express fluorescent proteins under the control of the vasa promoter (Krovel and Olsen, 2002; Filby et al., 2014), making it possible to easily monitor PGCs during development (Krovel and Olsen, 2002). These lines are also useful to isolate pure populations of PGCs and germ cells by fluorescence-activated cell sorting for different applications, such as germ cell transplantation. In fish, for example, vasa::egpf zebrafish (enhanced green fluorescent protein under vasa promoter) was used to isolate spermatogonial stem cell population prior germ cell transplantation (Nobrega et al., 2010; Tonelli et al., 2017).

Germ cell transplantation is a powerful technique that consists of isolating germ cells (PGCs or spermatogonia) from a donor fish and transplanting them into larvae of recipient species during early gonad development (Takeuchi et al., 2003; Okutsu et al., 2006). After transplantation, donor germ cells migrate towards the gonadal ridge and colonize the available niches, originating donor-derived gametes in the adults. Therefore, transplanted animals can function as surrogate broodstock parents by producing offspring with donor genetic characteristics (Takeuchi et al., 2003; Takeuchi et al., 2004; Okutsu et al., 2006). This technique has been successfully described in fish, including salmonids, tilapia, zebrafish and marine species (see review in Lacerda et al., 2010; Nobrega et al., 2010). However, to establish this technique, characterization of early gonadal development in fish larvae is considered one of the most important prerequisites. Molecular markers to identify PGCs in association with morphological analysis would provide a useful tool for characterizing early gonadal development in fish larvae. Moreover, the use of molecular markers for identifying early germ cells would also be applied for selecting PGCs or spermatogonia before transplantation (Takeuchi et al., 2003; Takeuchi et al., 2004; Okutsu et al., 2006; Nobrega et al., 2010).

Considering vasa as the most commonly used molecular marker for the germ cell line, and Jundiá, Rhamdia quelen (Heptapteridae, Siluriformes) as a potential model for germ cell transplantation as reported by Silva et al. (2016), this work aimed to clone and characterize the full-length $R$. quelen vasa cDNA. After cloning, we examined vasa expression during embryonic and larval development by real-rime, quantitative PCR ( $\mathrm{PPCR}$ ) and in situ hybridization, showing the usefulness of vasa as a molecular marker of PGCs. We also observed PGC migration towards the developing gonadal ridge, which we consider as crucial information to establish the germ cell transplantation technique in this species. In summary, we characterized vasa in a neotropical species with great economical importance in aquaculture and showed that vasa could be used as a germ cell marker for biotechnological studies in this species.

\section{Material and methods}

\subsection{Ethics statement}

All experimental procedures followed the guidelines for the ethical animal treatment and were approved by the Ethics Committee for animal experimentation of the São Paulo State University (protocol number 02248/14). Using approved anesthetics, all efforts were made to minimize discomfort and suffering during experimental procedures.

\subsection{Animal stocks and sampling}

Jundiá (R. quelen, Heptapteridae, Siluriformes) is a neotropical species with a wide distribution from central Argentina until south Mexico (Silfvergrip, 1996). It is considered one of the most promising native species for intensive fish farming due to its great economic interest within freshwater fish cultures, elevated commercial acceptance, elevated sperm production and short sexual maturation (6-8 months) (Ghiraldelli et al., 2007).

All specimens used in this study were reared at Institute for Research in Environmental Aquaculture (InPAA), PR Brazil. Jundiás ( $R$. quelen) were kept in freshwater tanks of $200 \mathrm{~m}^{2}$ under ambient photothermal conditions. Broodstock males and females were used for artificially induced spawning in order to produce eggs and sperm. The eggs were distributed into a conical PVC incubator of 2001 of volume at $22^{\circ} \mathrm{C}$. Embryos and larvae at different developmental stages were collected: at $0 \mathrm{~h}$ post-fertilization (hpf) (single cell stage), $4 \mathrm{hpf}$ (blastula stage), $7 \mathrm{hpf}$ (gastrula stage), $10 \mathrm{hpf}$ ( $90 \%$ epiboly) $13 \mathrm{hpf}$ (blastopore closure and germ ring), $16 \mathrm{hpf}, 19 \mathrm{hpf}, 22 \mathrm{hpf}, 25 \mathrm{hpf}$ (somite/segmentation stage), $31 \mathrm{hpf}, 37 \mathrm{hpf}$ (hatching), $43 \mathrm{hpf}$ and $49 \mathrm{hpf}$ (pigmentation of eyes and mouth opening). At this point, $24 \mathrm{~h}$ intervals were used to collect samples for RNA extraction and in situ hybridization. Each sample consisted of a pool of $100 \mathrm{mg}$ of embryos or larvae. In addition, adult males and females ( $\mathrm{n}=3$ males; 3 females) were euthanized by immersion in water containing benzocaine hydrochloride $(250 \mathrm{mg} / \mathrm{l})$. The embryonic and larval development of $R$. quelen is shown in Supplemental material (Supplemental Figs. 1 and 2). Different tissues (brain, gills, heart, liver, muscle, gut, kidney, gonads) were dissected and further processed for RNA extraction or in situ hybridization (gonads only).

\subsection{Molecular cloning of $R$. quelen vasa cDNA}

Total RNA from testes was extracted according to the FastRNA Pro Green Kit (MP Biomedicals, Solum, OH, USA), following the manufacturer's recommendations. To avoid genomic contamination, RNA was treated with DNase I (Invitrogen, Carlsbad, CA, USA) prior to cDNA synthesis. The cDNA synthesis was performed with random hexamers using Superscript II (Invitrogen, Carlsbad, CA, USA). Primers RqvasaRTFw and RqvasaRT-Rv (Table 1) to specifically PCR amplify a partial $R$. quelen vasa cDNA sequence were based on vasa sequences of catfish (Clarias gariepinus - NCBI:GU562470) and southern catfish (Silurus meridionalis - NCBI: EU532191). To obtain a full-length $R$. quelen vasa CDNA, 5'-RACE and 3'-RACE were performed using the SMART RACE cDNA amplification kit (Clontech, Mountain View,CA, USA), using $2 \mu \mathrm{g}$ total RNA and gene-specific primers (Table 1) designed based on the partial cDNA sequence obtained above in combination with UPM and NUP primers, supplied with the kit. PCR products were separated by gel electrophoresis and bands of the expected size were gel extracted, cloned into pcDNA3.1/V5-His TOPO vector (Invitrogen, Breda, The Netherlands) and sequenced. A Vasa amino acid sequence was deduced from the full-length $R$. quelen vasa cDNA sequence and aligned with other Vasa sequences, using ClustalW2 tool (http://www.ebi.ac.uk/ Tools/msa/clustalw2/) at default settings. To determine the possible protein domains, Pfam (http://pfam.sanger.ac.uk/) was used. Phylogenetic analyses were performed by the Neighbor joining (NJ) method, which determine the phylogenetic distance through a heuristic search with 1000 initiation replicates. A consensus cladogram without rooting (MEGA version 6.06) was generated.

\section{4. vasa expression: $R T-P C R, q P C R$ and in situ hybridization}

vasa expression was determined during embryogenesis, larval development and in several tissues (brain, gills, heart, liver, muscle, gut, eye, gonads) from male and female using reverse transcriptase-PCR (RT-PCR) and real-time, quantitative RT-PCR (qPCR). For all of these methods, total RNA was extracted with Trizol reagent (Life Technologies), followed by DNAse treatment and cDNA synthesis according to standard protocols (Nobrega et al., 2010). RT-PCR and qPCR 
Table 1

List of primers used for cloning and expression analysis of vasa. RACE, rapid amplification of cDNA ends; RT-PCR, reverse transcription-polymerase chain reaction; ISH, in situ hybridization; qPCR, real-time, quantitative polymerase chain reaction.

\begin{tabular}{|c|c|c|}
\hline Primers name & Sequence $\left(5^{\prime}-3^{\prime}\right)$ & Usage \\
\hline vasaFw3'-UPM (4156) & CAACCCACCCAAGGCTATCATGACAATCATGACATTTGAAGAA & RACE \\
\hline vasaFw3'-NUP (4157) & GCCCAATTGTGTGAGACACTGAACAAAAATGTTGCTAAGT & RACE \\
\hline vasaRv3'-NUP (4167) & ATACTTCTGAACAGGGGTAGGTTTCACGTATCCAGACTTA & RACE \\
\hline vasaRv3'-UPM (4164) & TTCCCTGATCCAGTCTGGGCACAAGCCATGAGATC & RACE \\
\hline vasaRv3'-NUP (4165) & CACAAGCCATGAGATCCCTCCCAGCAGATAT & RACE \\
\hline vasaRv3'-NUP (4166) & CCCAGCAGATATGATGGGAATTCCATACTTCTGAACA & RACE \\
\hline vasaRv3'-UPM (4163) & ACСTTCATTCATCAGATGCTGCAGAATAGGCAGC & RACE \\
\hline vasaRv3'-NUP (4159) & CGTTGGTGCCTCCATAAACGACAACAGGACG & RACE \\
\hline vasaRv3'-UPM (4158) & CACTTCTCGGATTGTAAATCCGACGTTGGTGC & RACE \\
\hline RqvasaRT-Fw & GGCAGAGGTGGGCGTGGGGGAAG & RT-PCR \\
\hline RqvasaRT-Rv & CCACGACCAATAATGTCAAGCAATCTTCCAGGG & RT-PCR \\
\hline RT- $\beta$-actin-Fw & TGACCTGACTGACTACCTCA & RT-PCR \\
\hline RT- $\beta$-actin-Rv & AGCTCATAGCTCTTCTCCAGGGGCGGGTGTTATTAACCCTCACTAAAGAGGCT & RT-PCR \\
\hline RqvasaT3-Fw & ATCATGACATTTGAAGAAG & ISH \\
\hline RqvasaT7-Rv & CCGGGGGGTGTAATACGACTCACTATAGACACAGGTGCCATAAGCA & ISH \\
\hline Rqvasa-qPCR-Fw & AGGCTATCATGACATTTGAAGAAG & qPCR \\
\hline Rqvasa-qPCR-Rv & CCATACTTCTGAACAGGGGT & qPCR \\
\hline
\end{tabular}

were conducted using specific primers for Rqvasa and $\beta$-actin (NCBI: EU527190) (Table 1). For RT-PCR, the amplified products were separated on $1 \%$ agarose gel and the expected bands were compared to the molecular weight of the ladder. For qPCR, Cq values for Rqvasa were determined using SYBR Green kit (Invitrogen) while Cq values for the reference gene (eukaryotic $18 S$ rRNA) expression were determined with an Invitrogen assay in combination with a Universal TaqMan kit (Invitrogen). All qPCR reactions $(20 \mu \mathrm{l})$ were performed in a StepOne system (Life Technologies) following the manufacturer's instructions, and relative gene expression profiles were calculated according to the $\Delta \Delta \mathrm{Ct}$ method as described previously (Vischer et al., 2003). Riboprobe synthesis for in situ hybridization was done using a $R$. quelen vasa-specific PCR product generated with primers RqvasaT3-Fw and RqvasaT7Rv (Table 1). The 384 bp PCR product was gel purified, and served as a template for digoxigenin (DIG)-labelled cRNA probe synthesis using the RNA labeling (Roche) kit. For in situ hybridization, embryo, larvae and gonads were fixed in $4 \%$ paraformaldehyde (PFA) in PBS at $4{ }^{\circ} \mathrm{C}$ overnight. The protocol used for whole mount (WISH) and in situ hybridization (paraffin embedded) were performed with adaptations, as described previously (Thisse and Thisse, 2008). Detection of hybridization signal was done with chromogen BCIP/NBT.

\subsection{Light microscopy}

For light microscopy, gonads were fixed in modified Karnovsky solution (2\% glutaraldehyde and 4\% paraformaldehyde in Sorensen buffer [0.1 M, pH 7.2]) for at least $24 \mathrm{~h}$, dehydrated in a graded ethylic series, embedded in Historesin (Leica HistoResin), sectioned $(3 \mu \mathrm{m}$ thickness) and stained with hematoxylin an eosin. The histological sections were examined and documented using Leica DMI6000 microscope (Leica).

\subsection{Statistical analysis}

Results were expressed as mean values \pm SEM. Significant differences between two groups were identified using unpaired Student test $(\mathrm{p}<0.05)$. Comparisons of more than two groups were performed with one-way ANOVA followed by Student-Newman-Keuls test ( $p<0.05)$. Graph Pad Prism 4.0 (Graph Pad Software, Inc., San Diego, CA, USA, (http://www.graphpad.com) was used for all statistical analysis.

\section{Results}

\subsection{Molecular characterization of Rqvasa cDNA}

The full-length $R$. quelen vasa cDNA consists of $2681 \mathrm{bp}$, comprising a $5^{\prime}$-UTR of $150 \mathrm{bp}$, open-reading frame of $2016 \mathrm{bp}$, and a $3^{\prime}$-UTR of 515 bp (Fig. 1). The deduced $R$. quelen Vasa protein is composed of 671 amino acids, containing eight consensus motifs characteristic of the DEAD-box protein family: an N-terminal region rich in glycine $(G)$ and arginine (R) residues - RGG and RG motifs- and a highly acidic Cterminal region composed of tryptophan (W), glutamic acid (E) and aspartic acid (D) (Fig. 1). The DEAD/DEAH box helicase (DEAD) domain is composed of 180 amino acids and the superfamily Helicase Cterminal (Helicase C) of 77 amino acids (Fig. 1). BLAST analysis revealed that DEAD (green box) and Helicase $C$ amino acid sequences showed high similarity with their respective homologs in other animals (Fig. 2). In this work, we did not find any isoform of $R$. quelen vasa mRNA (Supplemental material and methods). Phylogenetic analysis of the DEAD-box protein family revealed that $R$. quelen Vasa segregated with the VASA subfamily and did not cluster with the related proteins P68 or PL10 (Fig. 3). The NJ phylogenetic tree showed that all teleosts were clustered in one clade, suggesting a close relationship in this group with regards to Vasa (Fig. 3). Higher similarity was found between the $R$. quelen Vasa protein and other Vasa proteins in Siluriformes species (C. batrachus, C gariepinus and S. meridionalis) (Fig. 3). In the fish group, Siluriformes formed a sister group with Cypriniformes, and both showed a closer relationship with Salmoniformes and Anguilliformes (Fig. 3).

\subsection{Tissue distribution of Rqvasa mRNA}

qPCR and RT-PCR analysis of several tissues from adult male and female $R$. quelen showed that vasa mRNA was exclusively expressed in the gonads (Fig. 4, Supplemental Fig. 3A). Significantly higher vasa mRNA levels were found in ovary than in testis, while other tissues tested did not express detectable vasa mRNA (Fig. 4, Supplemental Fig. 3A).

\subsection{Expression of R. quelen vasa mRNA during embryonic development and larval stages}

The vasa expression levels were analyzed during embryogenesis, from zygote to the hatching stage, and during larval phase, from hatching until $264 \mathrm{hpf}$ by qPCR and RT-PCR (Fig. 5, Supplemental Fig. 3B). vasa transcripts were detected in the fertilized oocytes ( $0 \mathrm{hpf}$ ), 


\begin{tabular}{|c|c|}
\hline \multicolumn{2}{|l|}{ cacagcaggctcacaggaccagct } \\
\hline cgacatttactatagccttcttcttagttcaaaccagtctcacagcttcgagagatgtcacag & \\
\hline & \\
\hline & \\
\hline $\begin{array}{lllllllllllll}\mathbf{E} & \mathrm{Q} & \mathrm{S} & \mathrm{P} & \mathrm{V} & \mathrm{V} & \mathrm{T} & \mathrm{S} & \mathrm{L} & \mathrm{T} & \mathrm{L} & \mathrm{G} \\
\end{array}$ & \\
\hline & \\
\hline $\begin{array}{llllllllllllllllllll}A & W & N & S & N & G & Q & Q & N & G & K & D & N & E & E & S & S & W & K & P\end{array}$ & \\
\hline GCTGGTTTTGGGACTCAGGGGGGAAACAGAGATCGGGGGTTTGGAAAAGTTGATGGAGAC & \\
\hline$\underline{R} \quad \mathbf{G} \quad \mathrm{F}$ & \\
\hline CAAGGGCTTCAGAACAGGAATTGATGAAAATGCAAATGAAGGAGTTGATAATGGCCACTCC & \\
\hline $\begin{array}{llllllllllllll}T & G & I & D & E & N & A & N & E & G & V & D & N & G\end{array}$ & \\
\hline GAACACTGGTGGAGAGGGCTTTAGCGGACGAGGAGGCAGAGGACGAGGAGGACGAGGAGGA & \\
\hline $\begin{array}{llllllllllllllllll}N & \mathrm{~T} & \mathrm{G} & \mathrm{G} & \mathrm{E} & \mathrm{G} & \mathrm{F} & \mathrm{S} & \mathrm{G} & \mathbf{R} & \mathbf{G} & \mathbf{G} & \mathbf{R} & \mathbf{G} & \mathbf{R} & \mathbf{G} & \mathbf{G} & \mathbf{R} \\
\end{array}$ & \\
\hline & \\
\hline G & \\
\hline AGTGGCTTTAGTGGCAGAGGTGGGCGTGGAGGAAGAGGAGGCCGTGGAGCTTTCCAACAAGGT & \\
\hline $\begin{array}{lllllllllllllllllll}\mathrm{S} & \mathrm{G} & \mathrm{F} & \mathrm{S} & \mathrm{G} & \mathbf{R} & \mathbf{G} & \mathbf{G} & \underline{\mathbf{R}} & \mathbf{G} & \mathbf{G} & \mathbf{R} & \mathbf{G} & \mathbf{G} & \mathbf{R} & \mathbf{G} & \mathrm{A} & \mathrm{F} & \mathrm{Q}\end{array}$ & \\
\hline GGTGATGAAGAAGGCAAAGGACGCTTTGGTGGAGGCTATAGAGGACA GAACGAGGAGATATTT & \\
\hline $\begin{array}{llllllllllllllll}G & K & G & R & F & G & G & G & Y & \underline{R} & G & Q & N & E & E & I\end{array}$ & \\
\hline TCAAAGGGATCACCAAAGGATAACGAGGAAAAAGAAGATGGTGAGACTGCAGGGCCTAAGGTC & 07 \\
\hline $\begin{array}{llllllllllllllll}P & K & D & N & E & E & K & E & D & G & E & T & A & G & P & K\end{array}$ & \\
\hline ААСТATATTCCACCGCCACCACCGGAAGAGGAGAACTCCATTTTTTCTCACTACGCAACAGGC & \\
\hline $\begin{array}{lllllllllllllllllllll}N & Y & I & P & P & P & P & P & E & E & E & N & S & I & F & S & H & Y & A & T & G\end{array}$ & \\
\hline АTCAACTTTGACAGGTATGATGACATCCTGGTGGATGTAAGCGGAAGCAACCCACCCAAGGCT & 33 \\
\hline $\begin{array}{lllllllllllllllllllll}I & N & F & D & R & Y & D & D & I & L & V & D & V & S & G & S & N & P & P & K & A\end{array}$ & \\
\hline TCATGACATTTGAAGAAGCCCAATTGTGTGAGACACTGAACAAAAATGTTGCTAAGTCTGGA & \\
\hline $\begin{array}{lllllllllllllllllllll}I & M & \mathrm{~T} & \mathrm{~F} & \mathrm{E} & \mathrm{E} & \mathrm{A} & \mathrm{Q} & \mathrm{L} & \mathrm{C} & \mathrm{E} & \mathrm{T} & \mathrm{L} & \mathrm{N} & \mathrm{K} & \mathrm{N} & \mathrm{V} & \mathrm{A} & \mathrm{K} & \mathrm{S} & \mathrm{G}\end{array}$ & \\
\hline IACGTGAAACCTACCCCTGTTCAGAAGTATGGAATTCCCATCATATCTGCTGGGAGGGATCTC & y5 \\
\hline $\begin{array}{lllllllllllllllllll}V & K & P & T & P & V & Q & K & Y & G & I & P & I & I & S & A & G & R & D\end{array}$ & 2 \\
\hline TGGCTTGTGCCCAGACTGGATCAGGGAAAACGGCTGCCTTCCTGCTGCCTATTCTGCAGCAT & 1022 \\
\hline T G & 29 \\
\hline VAAGGTTTAGCATCCAGCAAGTTCAGTGAGCTGCAGGAGCCTGAAGTCATCATT & 1085 \\
\hline L A & \\
\hline GTTGCGCCCACTCGGGAACTCATTAATCAGATTTACCTAGAAGCCCGCAAGTTTGCTTATGGC & 114 \\
\hline 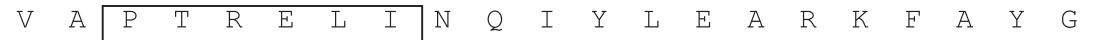 & 336 \\
\hline GCGTCCTGTTGTCGTTTATGGAGGCACCAACGTCGGATTTACAATCCGAGAAGTG & 1211 \\
\hline $\begin{array}{lllllllllllllllllllll}T & \mathrm{C} & \mathrm{V} & \mathrm{R} & \mathrm{P} & \mathrm{V} & \mathrm{V} & \mathrm{V} & \mathrm{Y} & \mathrm{G} & \mathrm{G} & \mathrm{T} & \mathrm{N} & \mathrm{V} & \mathrm{G} & \mathrm{F} & \mathrm{T} & \mathrm{I} & \mathrm{R} & \mathrm{E}\end{array}$ & 35 \\
\hline TTAAAAGGTTGCAATGTGCTGTGTGGGACCCCTGGAAGATTGCTCGACATTATTAACCGTGGA & 1274 \\
\hline \begin{tabular}{lllll|lll|llllllllll}
$N$ & $V$ & $L$ & $C$ & $G$ & $T$ & $P$ & $G$ & $R$ & $L$ & $L$ & $D$ & $I$ & $I$ & $N$ & $R$ & $G$
\end{tabular} & 378 \\
\hline AAGGTTGGATTAAGTAAAATTCGTTTTTTGGTGCTGGATGAAGCTGATCGAATGTTGGATATG & 7 \\
\hline \begin{tabular}{lllllllllllll|lllll|lllll}
$K$ & $V$ & $G$ & $L$ & $S$ & $K$ & $I$ & $R$ & $F$ & $L$ & $V$ & $L$ & $D$ & $E$ & $A$ & $D$ & $R$ & $M$ & $L$ & $D$ & $M$
\end{tabular} & \\
\hline GGATTTGAGGCGGACATGCGAAAGCTGGTAAACTCTCCAGGAATGCCTTCTAAAGAAGAGCGA & \\
\hline $\begin{array}{cllllllllllllllllllll}G & \mathrm{~F} & \mathrm{E} & \mathrm{A} & \mathrm{D} & \mathrm{M} & \mathrm{R} & \mathrm{K} & \mathrm{L} & \mathrm{V} & \mathrm{N} & \mathrm{S} & \mathrm{P} & \mathrm{G} & \mathrm{M} & \mathrm{P} & \mathrm{S} & \mathrm{K} & \mathrm{E} & \mathrm{E} & \mathrm{R}\end{array}$ & \\
\hline СAAACCCTTATGTTCAGTGCCACTTACCCGGAAGATATTCAGAAGCTGGCAGCCGACTTCCTA & \\
\hline 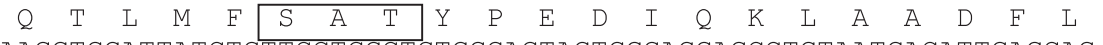 & \\
\hline AAGGTGGATTATCTGTTCCTGGCTGTGGGAGTAGTGGGAGGAGCCTGTAATGACATTGAGCAG & \\
\hline $\mathrm{L} \quad \mathrm{A} \quad \mathrm{V}$ & \\
\hline СACATCATTCAGGTCACTCAGTACTCAAAGAGGGAAAAGCTACTGGATCTGCTAAAGACTACA & \\
\hline $\begin{array}{llllllllllll}K & R & E & K & L & L & D & L & L & K & T & T\end{array}$ & \\
\hline GGGACACAGAGAACAATGGTCTTTGTTGAAACGAAACGAAGTGCAGATTTCATTGCAACATTC & \\
\hline $\begin{array}{llllllllllll}T & Q & R & T & M & V & F & V & E & T & K\end{array}$ & \\
\hline CTGTCAGGAAAAAATGCCCACTACAAGCATCCATGGCGATCGTGAACAGCGAGAGCGZ & \\
\hline $\begin{array}{llllllllllllllllllll}C & Q & E & K & M & P & T & T & S & I & H & G & D & R & E & Q & R & E & R & E\end{array}$ & \\
\hline GGCTCTCCGTGATTTCCGCACAGGCCAATGTCCTGTGCTGGTAGCTACTTCTGTTGCTGCT & 17 \\
\hline $\begin{array}{llllllllllllllllllll}A & L & R & D & F & R & T & G & Q & C & P & V & L & V & A & T & S & V & A & A\end{array}$ & \\
\hline
\end{tabular}

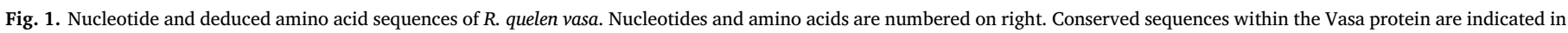

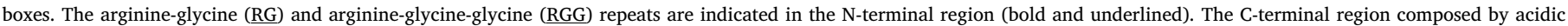

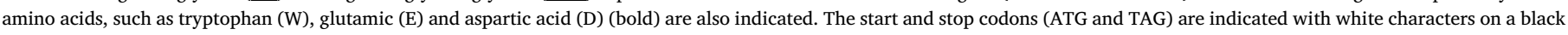
background. The polyadenylation signal (ataaa) and the poly-A tail are underlined. The sequence was deposited at GenBank (NCBI) with the access number KF640082.

which corresponds to the zygote stage (Fig. 5, Supplemental Fig. 3B). Following embryogenesis, from the first embryo cleavage ( $4 \mathrm{hpf}$ ) to gastrulation, a significant decrease in vasa expression levels was observed (Fig. 5, Supplemental Fig. 3B). During gastrulation (13 hpf), somitogenesis (16-37 hpf) and larval stages (43-264 hpf), the relative expression of $R$. quelen vasa remained constant (Fig. 5, Supplemental Fig. 3B). The Cq values of vasa transcripts were normalized with $18 \mathrm{~S}$ rRNA levels and expressed as values relative of the values at $0 \mathrm{hpf}$ (Fig. 5, Supplemental Fig. 3B). For comparative analysis, relative vasa mRNA levels in the adult testis are also shown (Fig. 5, Supplemental Fig. 3B).

\subsection{Localization of $R$. quelen vasa mRNA during embryonic and larval stages by WISH}

R. quelen vasa mRNA sites of expression were identified during embryonic and larval stages through chromogenic WISH. WISH showed that vasa transcripts were expressed in a restricted subset of cells distributed randomly around the blastoderm margin of a $90 \%$ epiboly stage embryo (gastrula - $10 \mathrm{hpf}$ ) (Fig. 6A,B). The vasa-expressing cells migrate through the shield and translocate from the epiblast to the hypoblast (Fig. 6C). During somitogenesis (19hpf), vasa mRNA was found in the PGCs which were associated to the yolk syncytial layer at 


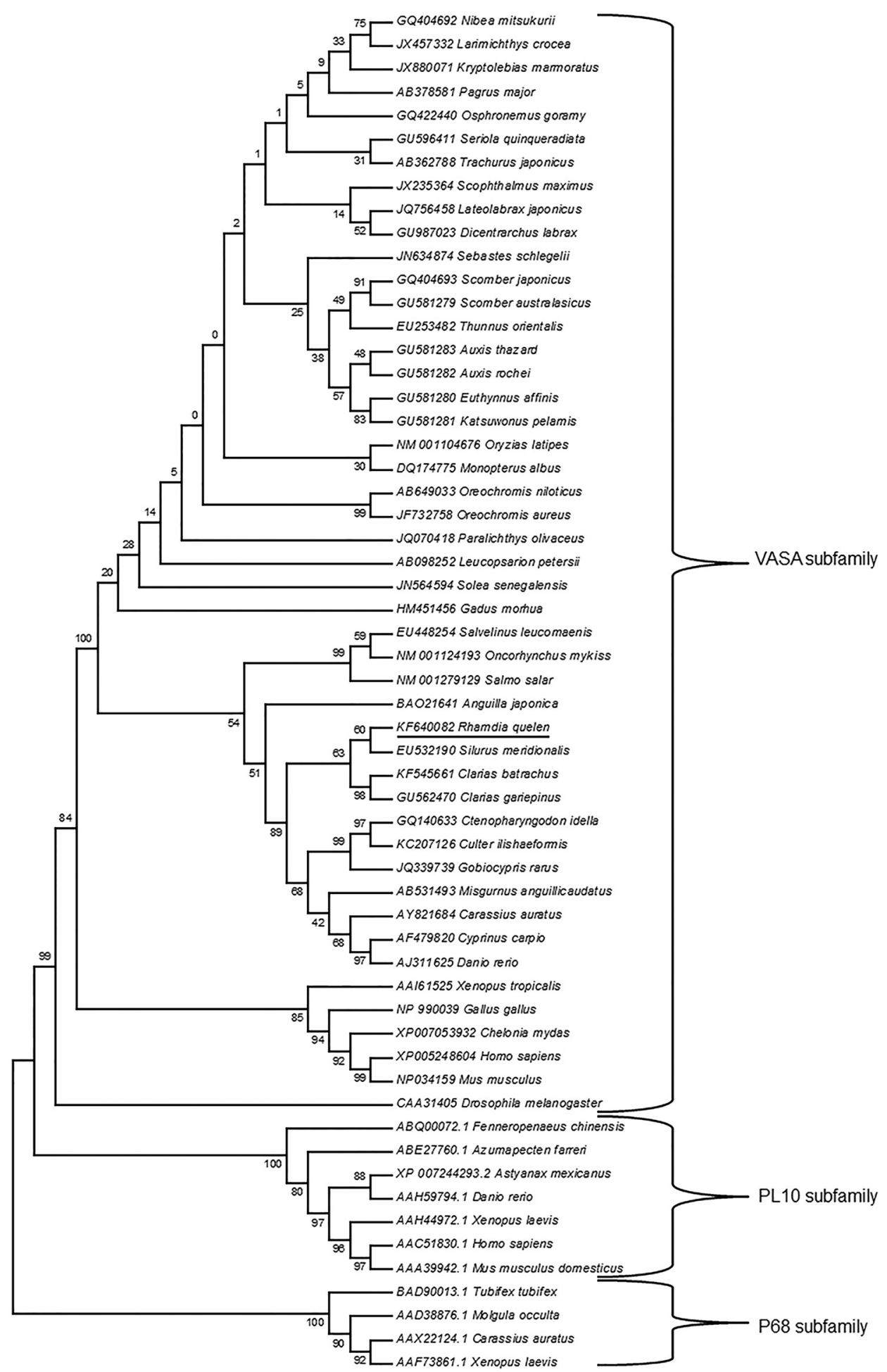

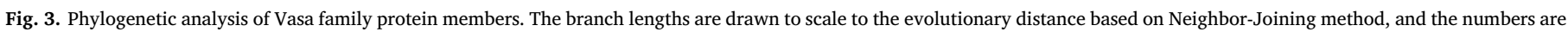

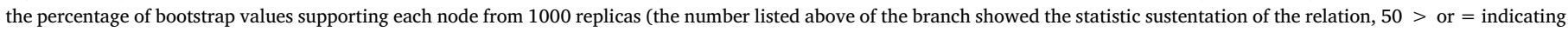

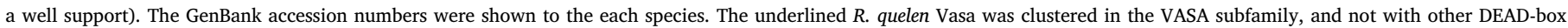
protein family members, such as PL10 and P68 subfamilies.

this stage (Fig. 6C). In the following stages (37, 43, 55, 72, 96 and $120 \mathrm{hpf}$ ), vasa transcripts were found in PGCs during their migratory process to the future gonad of the larva through the dorsal mesentery (Fig. 6D-L).

\subsection{Cellular localization of $R$. quelen vasa mRNA expression in the gonads}

Identification of specific cell types expressing the $R$. quelen vasa mRNA was accomplished by chromogenic in situ hybridization using ovary and testis paraffin-embedded sections of ovary and testis tissue (Figs. 7 and 8). Some ovaries were also subjected to WISH for detection of vasa transcripts (Fig. 7G). In the ovary, R. quelen vasa was mainly 


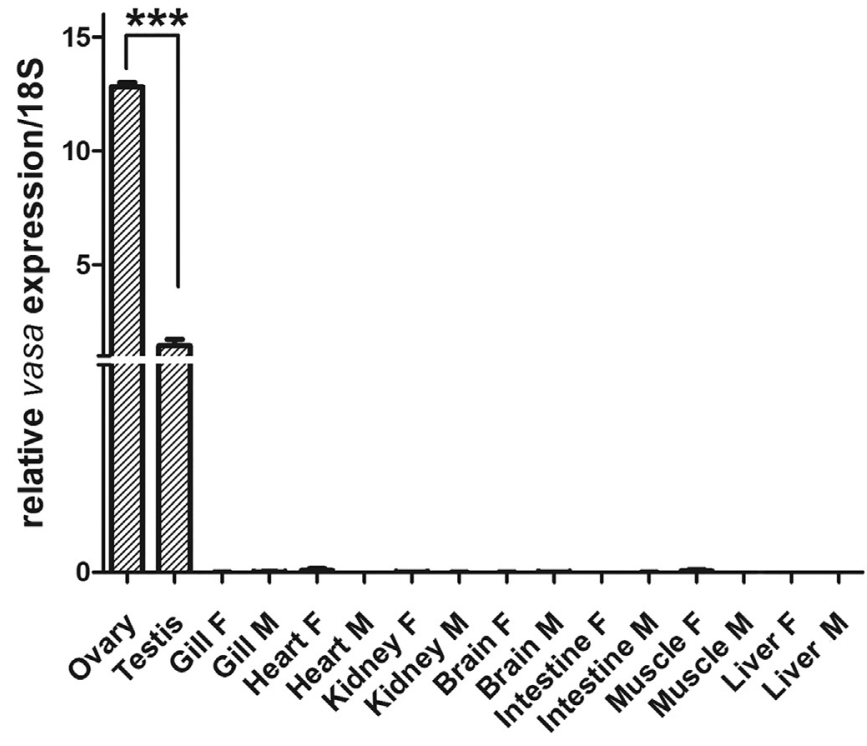

Fig. 4. Relative expression of $R$. quelen vasa mRNA in different adult tissues/organs from male (M) and female (F). cDNA from various tissues of adult fish (gill, heart, kidney, brain, intestine, muscle, testis, and ovary) were used for qPCR. The expression levels were normalized to the expression of $18 S$ rRNA (reference gene). Values represent mean \pm SEM relative to testicular vasa mRNA levels. The asterisks indicate a significant difference between testicular and ovarian tissue $(\mathrm{p}<0.05)$.

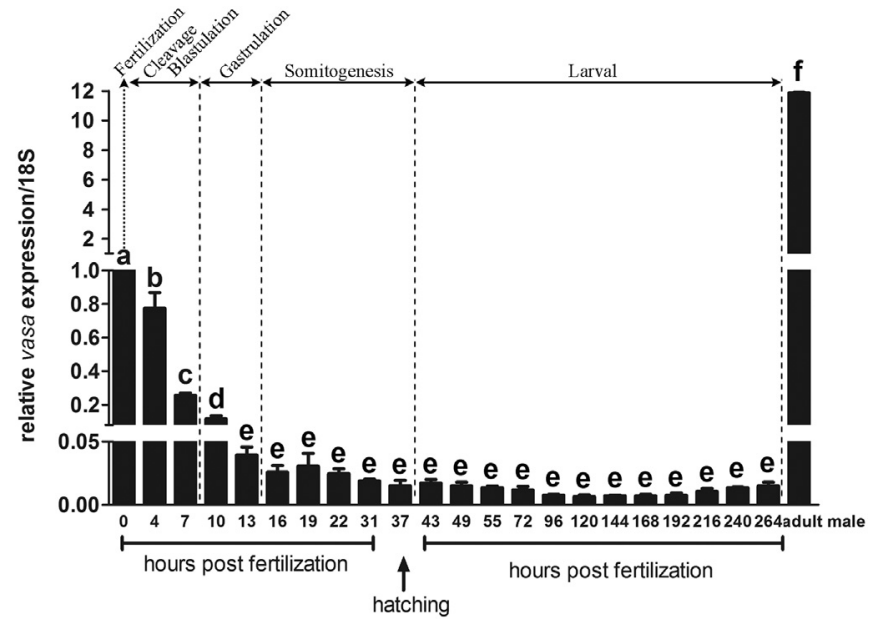

Fig. 5. The relative expression of $R$. quelen vasa mRNA during embryonic and larval development of $R$. quelen by qPCR. RNA was extracted from whole embryos at different stages of development from unfertilized eggs to $264 \mathrm{~h}$ post-fertilization (hpf). The expression of vasa mRNA was normalized to $18 S$ rRNA and expressed as relative values to vasa mRNA levels at $0 \mathrm{hpf}$. Expression of $R$. quelen vasa in testis from adult males is also shown. Data are expressed as mean \pm SEM. Different letters denote significant difference between each other ( $\mathrm{p}<0.05$, one-way ANOVA).

expressed in the perinucleolar oocyte stage (Fig. 7 D, E, F, G). In the early perinucleolar oocyte, vasa transcripts were found in the cytoplasm, and also in the nucleus, which showed a strong staining (Fig. 7D, F, G). In the late perinucleolar oocyte, vasa mRNA was found in the nucleolus, cytoplasm and in the Balbiani body (Fig. 7E). In the previtellogenic oocytes, $R$. quelen vasa was distributed uniformly in the cytoplasm (Fig. 7F). The signal is evidently less intense in vitellogenic oocytes, because of the decrease of vasa mRNA expression or its dispersion (Fig. 7E, F). In the WISH, the early germ cells are the ones presenting high intensity of vasa expression (Fig. 7G).

In the testis, vasa transcripts were exclusively expressed in the germ cells at different stages of spermatogenesis (Fig. 8 D, E, F). Germ cells develop within spermatocysts (or cysts), which are distributed along the germinal epithelium (Fig. 8 D,E). Spermatogonia (from type A until
B) presented the strongest signal for vasa mRNA, showing a mild decrease in intensity from type A spermatogonia to spermatids, and no signal in spermatozoa (Fig. 8 F).

\section{Discussion}

In the current study, we have isolated and characterized the fulllength vasa cDNA of a neotropical catfish species, Rhamdia quelen, and analyzed its expression profiles during embryogenesis and larval development. The deduced $R$. quelen Vasa protein has a Helicase $\mathrm{C}$ superfamily domain in the C-terminal and a DEAD-box in the N-terminal, as observed in D. labrax (Blazquez et al., 2011) and P. olivaceus (Wu et al., 2014). Both domains are typical of the Vasa protein family. The superfamily DEAD and Helicase C sequences of R. quelen Vasa shared high similarity with their respective homologs in other animals. Vasa, PL10 and P68 subfamilies are important DEAD-box protein family members. Phylogenetic analysis of Vasa proteins involved other DEADbox proteins from both vertebrates and invertebrates. Our results revealed that the $R$. quelen Vasa most closely resemble the Vasa subfamily instead of the other DEAD-box protein family members, such as the P68 and PL10 subfamilies, as shown in Cynoglossus semilaevis by Wang et al. (2014). Phylogenetic analysis showed that $R$. quelen Vasa is clustered with Vasa of other Siluriformes, such as C. batrachus, C. gariepinus and $S$. meridionalis. Moreover, our phylogenetic tree demonstrated that Siluriformes, Cypriniformes, Salmoniformes and Anguiliformes are evolutionarily related, indicating a monophyletic condition for the Vasa protein. In this work, we have not found other isoform for vasa mRNA in $R$. quelen gonads (see Supplemental material and methods), similarly as reported in the catfish C. gariepinus (Siluriformes) (Raghuveer and Senthilkumaran, 2010). S. meridionalis is the only catfish reported until now with different vasa isoforms in the gonads (Hu et al., 2008). Therefore, this work is the first one to characterize vasa mRNA from a neotropical catfish, showing one form of vasa transcript. More studies will be necessary to address if other neotropical catfish species do have one form of vasa mRNA or not.

We also evaluated the tissue distribution of vasa in male and female by RT-PCR and qPCR. vasa mRNA was predominantly expressed in the gonads, significantly higher in ovaries than in the testes. Similar results were found in invertebrates, such as Caenorhabditis elegans (Gruidl et al., 1996), D. melanogaster (Hay et al., 1988), and in vertebrates, as $D$. rerio (Yoon et al., 1997), C. gariepinus (Raghuveer and Senthilkumaran, 2010), P. olivaceus (Wu et al., 2014), Xenopus (Ikenishi and Tanaka, 2000) and others. In the gonads, vasa transcripts were found to be exclusively expressed in germ cells, as reported previously in D. melanogaster (Lasko and Ashburner, 1988), zebrafish (Yoon et al., 1997), rainbow trout (Yoshizaki et al., 2000), tilapia (Kobayashi et al., 2000), Xenopus (Komiya et al., 1994; Ikenishi and Tanaka, 2000), chicken (Tsunekawa et al., 2000) and others.

Interestingly, vasa was strongly expressed in germ cells at early stages of development in $R$. quelen gonads, as observed in other teleosts (Braat et al., 1999; Knaut et al., 2000; Xu et al., 2005), and decreased its expression as gametogenesis progresses. In spermatogenesis, $R$. quelen vasa showed a mild decrease in expression from type A spermatogonia to spermatids, and no signal in spermatozoa. Similar results were found in A. japonicus (Xu et al., 2005) and C. auratus gibelio (Xu et al., 2005), although in the latter one, vasa was not present in spermatids either (Xu et al., 2005). On the other hand, in Oreochromis niloticus, vasa mRNA was detected in all stages of germ cell development, from type A spermatogonia to spermatozoa (Kobayashi et al., 2000). Such variation of vasa expression in different species might be related to the function of vasa in spermatogenesis, however, very few information was obtained in the last years in this regard. In medaka, analysis of the Vasa protein during spermatogenesis suggests that this protein has an important role in cytodifferentiation and formation of the sperm tail during spermiogenesis (Yuan et al., 2014). This hypothesis was based due the presence of Vasa in the chromatoid body, which is a ring- 


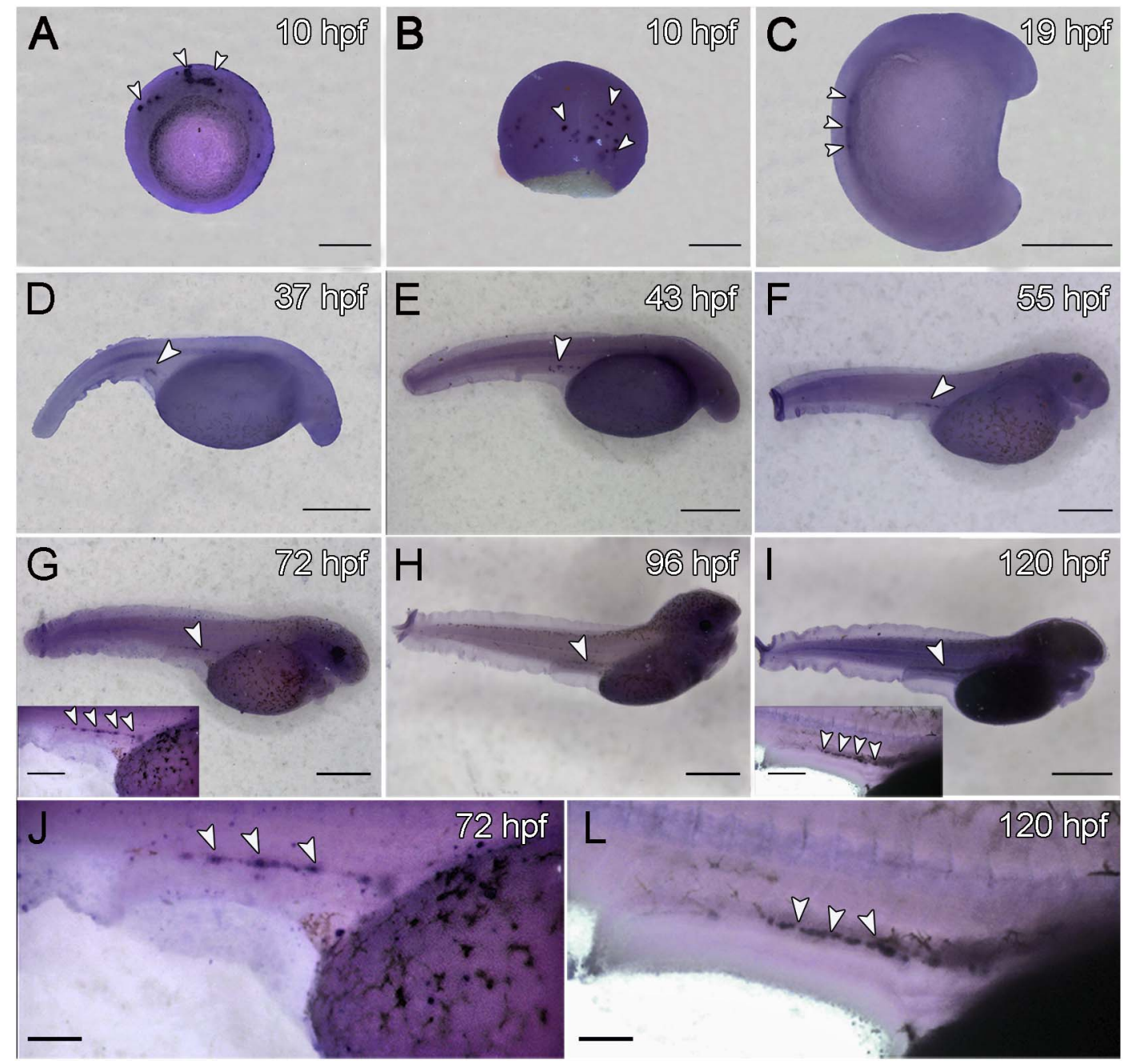

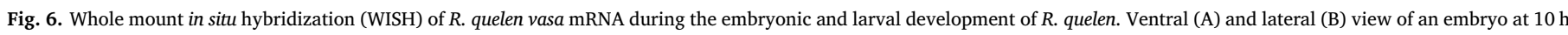

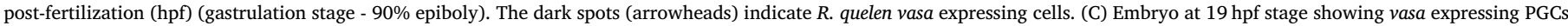

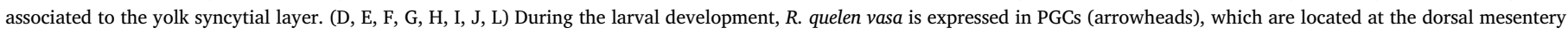
migrating towards the developing gonadal ridge. Bars: $\mathrm{A}-\mathrm{I}=500 \mu \mathrm{m} ; \mathrm{J}, \mathrm{L}=100 \mu \mathrm{m}$.

shaped structure surrounding the tail of the spermatids (Yuan et al., 2014). Interestingly, although the role of the chromatoid body is unclear, studies in mouse have demonstrated that the loss of the ringshaped structures resulted in male infertility (Shang et al., 2010). Moreover, recent studies showed that vasa is essential for spermatogenesis and not for oogenesis; e.g. loss of vasa homolog in mice and zebrafish resulted in defective spermatogenesis and male sterility, while oogenesis remained normal (Tanaka et al., 2000; Shang et al., 2010; Hartung et al., 2014).

In ovaries, $R$. quelen vasa is highly expressed in the perinucleolar oocyte, specifically in the cytoplasm, nucleus, nucleolus and in the Balbiani body. At the previtellogenic stage, R. quelen vasa is expressed in the cytoplasm, decreasing its expression in the vitellogenic oocyte. Such decrease is similar to the one found in L. calcarifer ( $\mathrm{Xu}$ et al., 2014), O. niloticus (Kobayashi et al., 2000), A. japonicus (Yan et al., 2013) and C. auratus gibelio, (Xu et al., 2005). Interestingly, in human (Homo sapiens), VASA protein was found in the primary follicles at the pubertal stage, and as follicle starts its growing, the protein is no longer detected (Albamonte et al., 2013). This variation of vasa expression during female germ cell development could be associated to processes of self-renewal, differentiation and meiosis (Xu et al., 2014). However, more studies are needed to unravel the role of vasa in oogenesis. Interestingly, in some organisms, this gene is essential for oogenesis. In $D$. melanogaster, for example, mutations in maternal inherited genes, such as vasa, showed that females did not complete oogenesis and are sterile (Schupbach and Wieschaus, 1991). On the other hand, in teleosts, vasa seems to be dispensable for female germ cell development, as mentioned above.

Changes in $R$. quelen vasa mRNA expression were analyzed from 0 to $264 \mathrm{hpf}$ in whole $R$. quelen embryos to investigate whether vasa mRNA is among the maternally contributed mRNAs and when $R$. quelen vasa mRNA expression starts during early embryonic development. In $R$. quelen embryos, vasa mRNA could be detected at $0 \mathrm{hpf}$, which suggests that vasa is maternally deposited in oocytes. Usually, maternally inherited factors (proteins, mRNAs) are deposited during oogenesis in structures so-called as germinative plasm and Balbiani body (Lasko and Ashburner, 1988). In this work, we localized the R. quelen vasa primary transcripts in Balbiani bodies at the perinucleolar stage (see above). The Balbiani body is a typical structure of female germinative cells, generally composed of mitochondria and electron dense granules with long duration RNAs (such as vasa mRNA) and proteins (Voronina et al., 2011). These structures remain along the embryo development, being responsible for the specification of the germ cell lineage in different organisms, such as D. melanogaster (Lasko and Ashburner, 1988), medaka (O. latipes) (Herpin et al., 2007) and others. In line with this, many studies have demonstrated maternally inherited vasa transcripts in oocytes (cytoplasm and Balbiani body) and early embryonic development stages in teleosts. In zebrafish, for example, vasa mRNA is detected very 

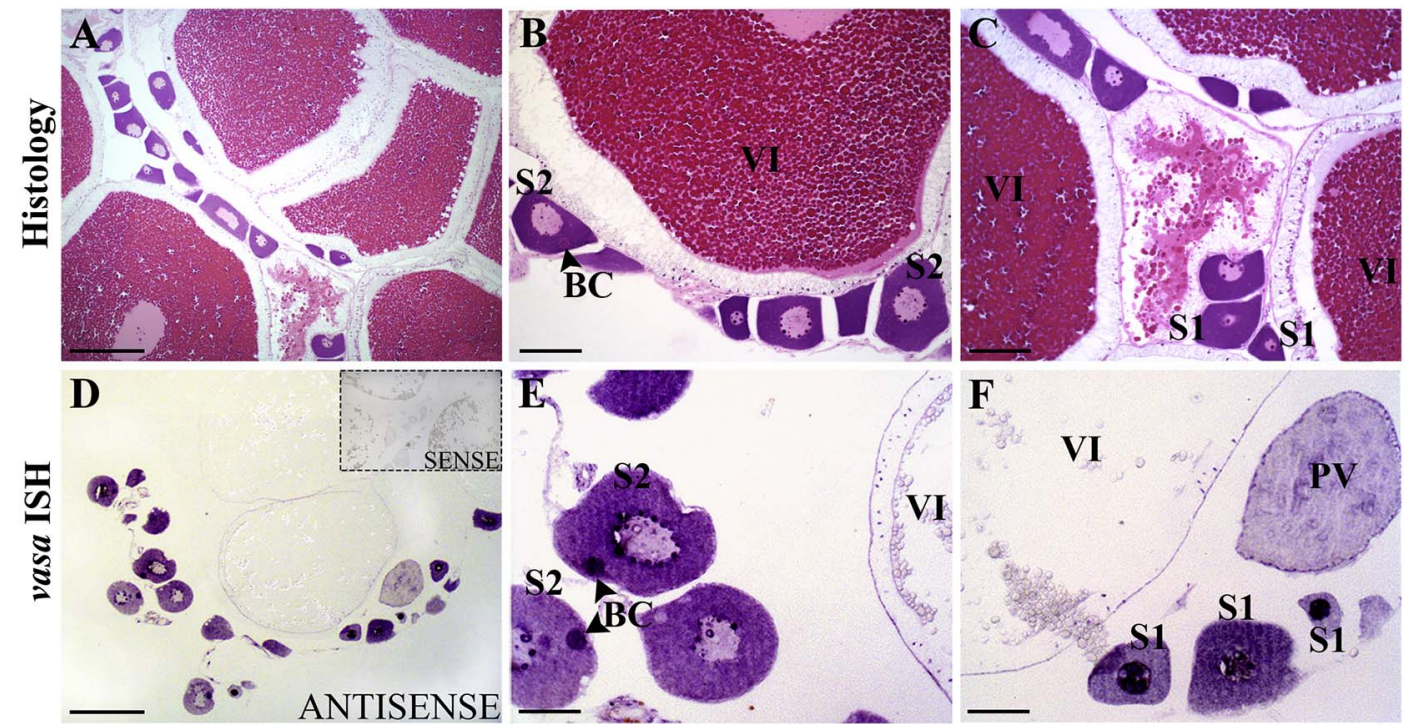

VI
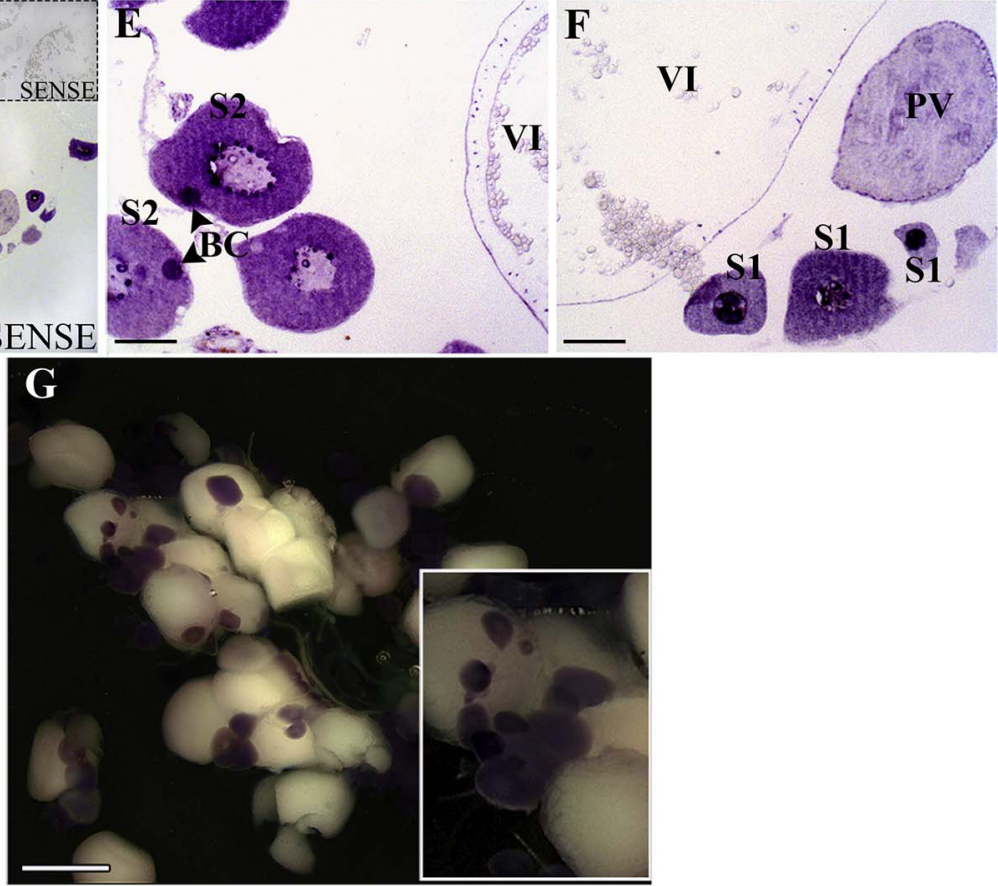

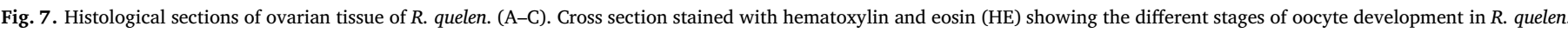

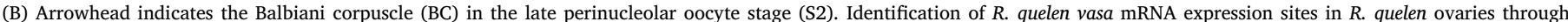

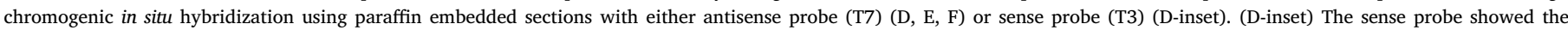

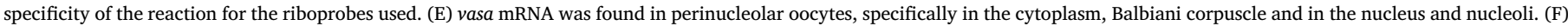

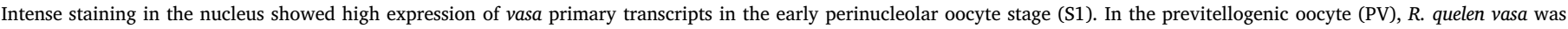

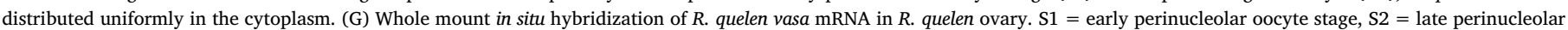
oocyte stage, $\mathrm{PV}=$ previtellogenic, $\mathrm{VI}=$ vitellogenic. Bars: $\mathrm{A}, \mathrm{D}=250 \mu \mathrm{m} ; \mathrm{B}, \mathrm{C}=100 \mu \mathrm{m} ; \mathrm{E}, \mathrm{F}=50 \mu \mathrm{m} ; \mathrm{G}=1000 \mu \mathrm{m}$.

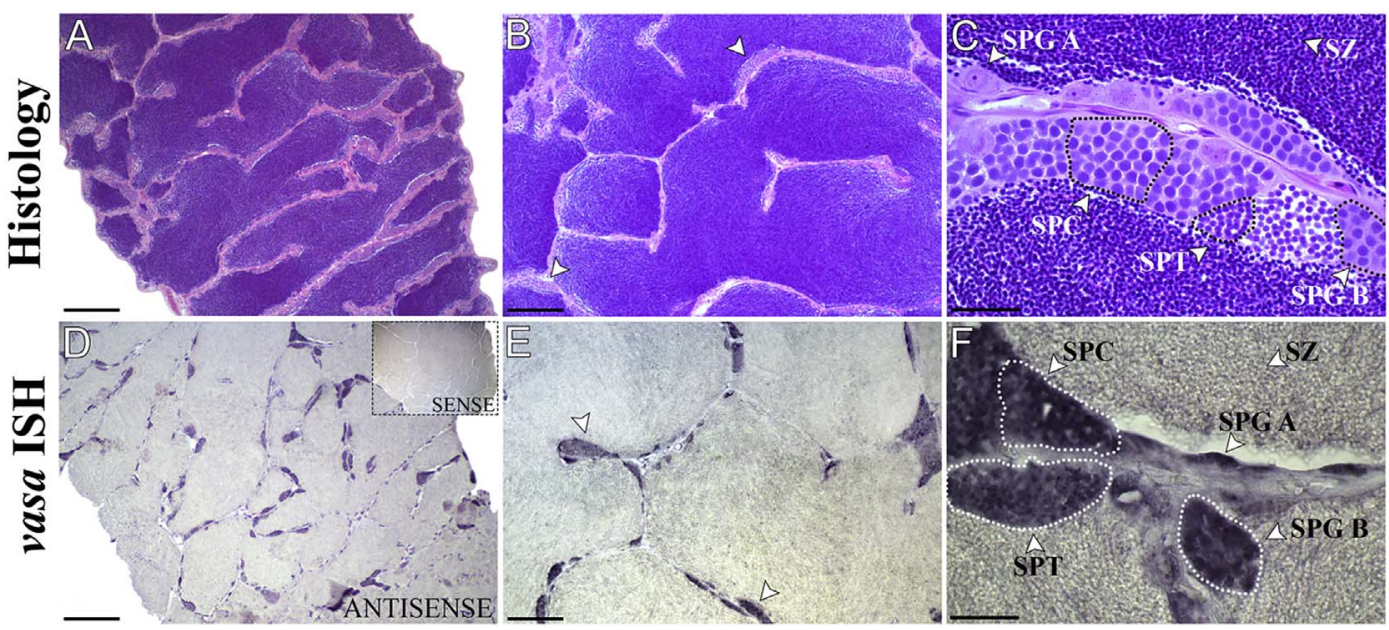

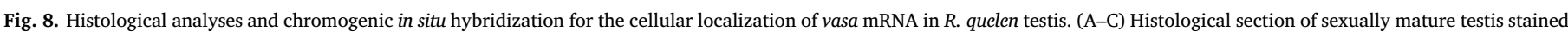

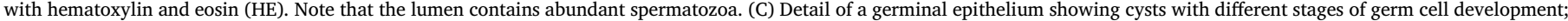

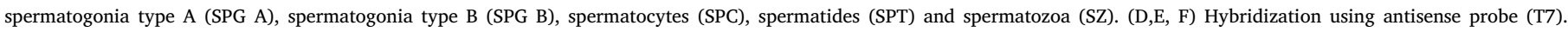

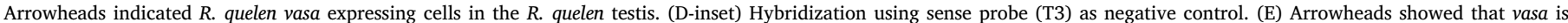

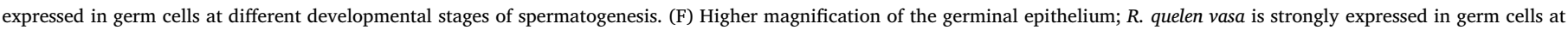
early stages of development. Bars: A, D $=250 \mu \mathrm{m} ; \mathrm{B}, \mathrm{E}=100 \mu \mathrm{m} ; \mathrm{C}, \mathrm{F}=25 \mu \mathrm{m}$. 
early during embryonic development, and embryonic vasa mRNA expression starts only at the medial blastula (Kane and Kimmel, 1993; Yoon et al., 1997). In this work, the presence of $R$. quelen vasa mRNA in oocyte (cytoplasm and Balbiani body) is another evidence of maternal inheritance of this transcript, which will contribute for the germline establishment in the embryos of this species.

The relative $R$. quelen vasa mRNA levels decreased significantly and gradually from 0 to $13 \mathrm{hpf}$, where it reached its lowest levels of expression and remained constant along the evaluated period ( $264 \mathrm{hpf}$ ). Interestingly, the lowest $R$. quelen vasa expression was also observed in the same period of the embryonic development of Japanese flounder (Wu et al., 2014), D. rerio (Wolke et al., 2002), gibel carp (Xu et al., 2005) and C. gariepinus (Raghuveer and Senthilkumaran, 2010). This observation might be explained due to maternal transcripts degradation or by the dilution of vasa transcripts because of the increased number of cells in the organism. The cellular sites expressing $R$. quelen vasa were identified in the whole embryo by WISH. We have observed that $R$. quelen vasa primary transcripts were expressed exclusively in the migrating PGCs. Thus, at the $10 \mathrm{hpf}$ ( $90 \%$ epiboly), PGCs were present at the dorsal region of the embryo, further translocating from the epiblast towards the hypoblast, similar as in Gymnogobius species (Saito et al., 2002). In the somitogenesis stage, PGCs were located at the mesoderm, in association with the syncytial layer of the yolk, as reported previously (Nagai et al., 2001; Saito et al., 2002; Saito et al., 2004). At the advanced larval stages (37, 43, 55, 72, 96 and $120 \mathrm{hpf}$ ), the vasa mRNA expressing PGCs were located in the dorsal mesentery, most likely in a migratory process towards the genital ridge. Such observation is similar to studies in zebrafish, where PGCs migration was identified at the five somite phase, at the border of the endoderm and contacting the syncytial layer of the yolk sac, followed by its migration from the dorsal mesentery to the genital ridge (Braat et al., 1999).

In summary, the current work has characterized the full-length vasa cDNA from a neotropical catfish species, $R$. quelen. We showed high similarity between the predicted amino acid sequence encoded by vasa and the other Vasa homologs, especially in the typical DEAD-box and Helicase C superfamily domains. R. quelen vasa mRNA expression seemed to be restricted to gonads, specific of the germ cell lineage. Expression analysis during the embryonic and larval development showed that vasa is maternally inherited and later is expressed in PGCs during their migratory process to the gonadal ridge. Our results contributed for basic knowledge of $R$. quelen reproductive biology, showing that $R$. quelen vasa is an useful germ cell marker for biotechnological studies, such as germ cell transplantation.

Supplementary data to this article can be found online at https:// doi.org/10.1016/j.gene.2018.02.029.

\section{Conflict of interest}

The authors declare no conflicts of interest.

\section{Acknowledgments}

This work was supported by Fundação de Amparo à Pesquisa do Estado de São Paulo (FAPESP, 14/07620-7 and 12/00423-6) and Coordenação de Aperfeiçoamento de Pessoal de Nível superior, Graduate Student Program (JMBR scholarship). JB is supported by the Norwegian Research Council BIOTEK2021 project SALMOSTERILE (221648). The authors would like to thank the Aquaculture Center of Sao Paulo State University (CAUNESP), Institute of Biosciences of Botucatu (IBB-UNESP) and Institute for Research in Environmental Aquaculture (InPAA). The authors are also grateful to Dr. Cesar Martins, Dr. Danillo Pinhal, Dr. Ivan de Godoy Maya, and Dra. Maeli Dal Pai for their technical assistance in this work. The authors would like to thank Msc. Sheryll Yohana Corchuelo Chavarro for drawing the Graphical abstract.

\section{References}

Albamonte, M.I., Albamonte, M.S., Stella, I., Zuccardi, L., Vitullo, A.D., 2013. The infant and pubertal human ovary: Balbiani's body-associated VASA expression, immunohistochemical detection of apoptosis-related BCL2 and BAX proteins, and DNA fragmentation. Hum. Reprod. 28, 698-706.

Blazquez, M., Gonzalez, A., Mylonas, C.C., Piferrer, F., 2011. Cloning and sequence analysis of a vasa homolog in the European sea bass (Dicentrarchus labrax): tissue distribution and mRNA expression levels during early development and sex differentiation. Gen. Comp. Endocrinol. 170, 322-333.

Braat, A.K., Zandbergen, T., van de Water, S., Goos, H.J., Zivkovic, D., 1999. Characterization of zebrafish primordial germ cells: morphology and early distribution of vasa RNA. Dev. Dyn. 216, 153-167.

Filby, A.L., Ortiz-Zarragoitia, M., Tyler, C.R., 2014. The vas::egfp transgenic zebrafish: a practical model for studies on the molecular mechanisms by which environmental estrogens affect gonadal sex differentiation. Environ. Toxicol. Chem. 33, 602-605.

Ghiraldelli, L., Machado, C., Fracalossi, D.M., 2007. Desenvolvimento gonadal do jundiá, Rhamdia quelen (Teleostei, Siluriformes) em viveiros de terra, na região sul do Brasil. Acta Sci. Biol. Sci. 29, 349-356.

Gruidl, M.E., Smith, P.A., Kuznicki, K.A., McCrone, J.S., Kirchner, J., Roussell, D.L., Strome, S., Bennett, K.L., 1996. Multiple potential germ-line helicases are components of the germ-line-specific P granules of Caenorhabditis elegans. Proc. Natl. Acad. Sci. U. S. A. 93, 13837-13842.

Hartung, O., Forbes, M.M., Marlow, F.L., 2014. Zebrafish vasa is required for germ-cell differentiation and maintenance. Mol. Reprod. Dev. 81, 946-961.

Hay, B., Ackerman, L., Barbel, S., Jan, L.Y., Jan, Y.N., 1988. Identification of a component of Drosophila polar granules. Development 103, 625-640.

Herpin, A., Rohr, S., Riedel, D., Kluever, N., Raz, E., Schartl, M., 2007. Specification of primordial germ cells in medaka (Oryzias latipes). BMC Dev. Biol. 7, 3.

Hickford, D.E., Frankenberg, S., Pask, A.J., et al., 2011. DDX4 (VASA) is conserved in germ cell development in marsupials and monotremes. Biol. Reprod. 85 (4), 733-743.

Hu, C.J., Wu, F.R., Liu, Z.H., Huang, B.F., Zhang, Y.G., Wang, D.S., 2008. Molecular cloning and expression of two isoforms of vasa gene in southern catfish Silurus meriodinalis. Acta Zool. Sin. 54 (6), 1051-1060.

Ikenishi, K., Tanaka, T.S., 1997. Involvement of the protein of Xenopus vasa homolog (Xenopus vasa-like gene 1, XVLG1) in the differentiation of primordial germ cells. Develop. Growth Differ. 39 (5), 625-633.

Ikenishi, K., Tanaka, T.S., 2000. Spatio-temporal expression of Xenopus vasa homolog, XVLG1, in oocytes and embryos: the presence of XVLG1 RNA in somatic cells as well as germline cells. Develop. Growth Differ. 42, 95-103.

Kane, D.A., Kimmel, C.B., 1993. The zebrafish midblastula transition. Development 119, 447-456.

Knaut, H., Pelegri, F., Bohmann, K., Schwarz, H., Nusslein-Volhard, C., 2000. Zebrafish vasa RNA but not its protein is a component of the germ plasm and segregates asymmetrically before germline specification. J. Cell Biol. 149, 875-888.

Kobayashi, T., Kajiura-Kobayashi, H., Nagahama, Y., 2000. Differential expression of vasa homologue gene in the germ cells during oogenesis and spermatogenesis in a teleost fish, tilapia, Oreochromis niloticus. Mech. Dev. 99, 139-142.

Komiya, T., Itoh, K., Ikenishi, K., Furusawa, M., 1994. Isolation and characterization of a novel gene of the DEAD box protein family which is specifically expressed in germ cells of Xenopus laevis. Dev. Biol. 162, 354-363.

Krovel, A.V., Olsen, L.C., 2002. Expression of a vas::EGFP transgene in primordial germ cells of the zebrafish. Mech. Dev. 116, 141-150.

Kuznicki, K.A., Smith, P.A., Leung-Chiu, W.M., et al., 2000. Combinatorial RNA interference indicates GLH-4 can compensate for GLH-1; these two P granule components are critical for fertility in C. elegans. Development 127 (13).

Lacerda, S.M., Batlouni, S.R., Costa, G.M., Segatelli, T.M., Quirino, B.R., Queiroz, B.M., Kalapothakis, E., Franca, L.R., 2010. A new and fast technique to generate offspring after germ cells transplantation in adult fish: the Nile tilapia (Oreochromis niloticus) model. PLoS One 5, e10740.

Lasko, P.F., Ashburner, M., 1988. The product of the Drosophila gene vasa is very similar to eukaryotic initiation factor-4A. Nature 335, 611-617.

Li, M., Hong, N., Xu, H., Yi, M., Li, C., Gui, J., Hong, Y., 2009. Medaka vasa is required for migration but not survival of primordial germ cells. Mech. Dev. 126, 366-381.

Linder, P., Lasko, P.F., Ashburner, M., Leroy, P., Nielsen, P.J., Nishi, K., Schnier, J. Slonimski, P.P., 1989. Birth of the D-E-A-D box. Nature 337, 121-122.

Mochizuki, K., Nishimiya-Fujisawa, C., Fujisawa, T., 2001. Universal occurrence of the vasa-related genes among metazoans and their germline expression in hydra. Dev. Genes Evol. 211, 299-308.

Nagai, T., Yamaha, E., Arai, K., 2001. Histological differentiation of primordial germ cells in zebrafish. Zool. Sci. 18, 215-223.

Nagasawa, K., Fernandes, J.M., Yoshizaki, G., Miwa, M., Babiak, I., 2013. Identification and migration of primordial germ cells in Atlantic salmon, Salmo salar: characterization of vasa, dead end, and lymphocyte antigen 75 genes. Mol. Reprod. Dev. 80, 118-131.

Nakamura, A., Seydoux, G., 2008. Less is more: specification of the germline by transcriptional repression. Development 135, 3817-3827.

Nobrega, R.H., Greebe, C.D., van de Kant, H., Bogerd, J., de Franca, L.R., Schulz, R.W., 2010. Spermatogonial stem cell niche and spermatogonial stem cell transplantation in zebrafish. PLoS One 5.

Okutsu, T., Yano, A., Nagasawa, K., Shikina, S., Kobayashi, T., Takeuchi, Y., Yoshizaki, G., 2006. Manipulation of fish germ cell: visualization, cryopreservation and transplantation. J. Reprod. Dev. 52, 685-693.

Presslauer, C., Nagasawa, K., Fernandes, J.M.O., Babiak, I., 2012. Expression of vasa and 
nanos3 during primordial germ cell formation and migration in Atlantic cod (Gadus morhua L.). Theriogenology 78, 1262-1277.

Raghuveer, K., Senthilkumaran, B., 2010. Cloning and differential expression pattern of vasa in the developing and recrudescing gonads of catfish, Clarias gariepinus. Comp. Biochem. Physiol. A Mol. Integr. Physiol. 157, 79-85.

Raz, E., 2003. Primordial germ-cell development: the zebrafish perspective. Nat. Rev. Genet. 4, 690-700.

Reitzel, A.M., Pang, K., Martindale, M.Q., 2016. Developmental expression of "germline" and "sex determination" related genes in the ctenophore Mnemiopsisleidyi. EvoDevo $7,17$.

Rocak, S., Linder, P., 2004. Dead-box proteins: the driving forces behind RNA metabolism. Nat. Rev. Mol. Cell Biol. 5, 232-241.

Saffman, E.E., Lasko, P., 1999. Germline development in vertebrates and invertebrates. Cell. Mol. Life Sci. 55, 1141-1163.

Saito, T., Otani, S., Fujimoto, T., Suzuki, T., Nakatsuji, T., Arai, K., Yamaha, E., 2004. The germ line lineage in ukigori, Gymnogobius species (Teleostei: Gobiidae) during embryonic development. Int. J. Dev. Biol. 48, 1079-1085.

Saito, T., Otani, S., Nagai, T., Nakatsuji, T., Arai, K., Yamaha, E., 2002. Germ cell lineage from a single blastomere at 8-cell stage in shiro-uo (ice goby). Zool. Sci. 19, 1027-1032.

Schupbach, T., Wieschaus, E., 1991. Female sterile mutations on the second chromosome of Drosophila melanogaster. II. Mutations blocking oogenesis or altering egg morphology. Genetics 129, 1119-1136.

Shang, P., Baarends, W.M., Hoogerbrugge, J., Ooms, M.P., van Cappellen, W.A., de Jong, A.A., Dohle, G.R., van Eenennaam, H., Gossen, J.A., Grootegoed, J.A., 2010. Functional transformation of the chromatoid body in mouse spermatids requires testis-specific serine/threonine kinases. J. Cell Sci. 123, 331-339.

Silfvergrip, A.M.C., 1996. A Sistematic Revision of the Neotropical Catfish Genus Rhamdia (Teleostei, Pimelodidae). pp. 156 Stockholm, Sweden, (PhD Thesis) Department of Zoology, Stockholm University and Department of Vertebrate Zoology, Swedish Museum of Natural History.

Silva, M.A., Costa, G.M.J., Lacerda, S.M.S.N., Brandão-Dias, P.F.P., Kalapothakis, E., Silva Júnior, A.F., Alvarenga, E.R., França, L.R., 2016. Successful xenogeneic germ cell transplantation from Jundia catfish (Rhamdia quelen) into adult Nile tilapia (Oreochromis niloticus) testes. Gen. Comp. Endocrinol. 230-231, 48-56.

Takeuchi, Y., Yoshizaki, G., Takeuchi, T., 2003. Generation of live fry from intraperitoneally transplanted primordial germ cells in rainbow trout. Biol. Reprod. 69, 1142-1149.

Takeuchi, Y., Yoshizaki, G., Takeuchi, T., 2004. Biotechnology: surrogate broodstock produces salmonids. Nature 430, 629-630.

Tanaka, S.S., Toyooka, Y., Akasu, R., Katoh-Fukui, Y., Nakahara, Y., Suzuki, R.,
Yokoyama, M., Noce, T., 2000. The mouse homolog of Drosophila vasa is required for the development of male germ cells. Genes Dev. 14, 841-853.

Thisse, C., Thisse, B., 2008. High-resolution in situ hybridization to whole-mount zebrafish embryos. Nat. Protoc. 3, 59-69.

Tonelli, Lacerda, Tonelli, Costa, de Franca, Resende, 2017. Biotechnol. Adv. 35 (6), 832-844.

Tsunekawa, N., Naito, M., Sakai, Y., Nishida, T., Noce, T., 2000. Isolation of chicken vasa homolog gene and tracing the origin of primordial germ cells. Development 127, 2741-2750.

Vischer, H.F., Teves, A.C., Ackermans, J.C., van Dijk, W., Schulz, R.W., Bojerd, J., 2003 Cloning and spatiotemporal expression of the follicle-stimulating hormone $§$ subunit complementary DNA in the African catfish (Clarias gariepinus). Biol. Reprod. 8, 1324-1332.

Voronina, E., Seydoux, G., Sassone-Corsi, P., Nagamori, I., 2011. RNA granules in germ cells. Cold Spring Harb. Perspect. Biol. 3.

Wang, Z., Gao, J., Song, H., Wu, X., Sun, Y., Qi, J., Yu, H., Wang, Z., Zhang, Q., 2014 Sexually dimorphic expression of vasa isoforms in the tongue sole (Cynoglossus semilaevis). PLoS One 9.

Wolke, U., Weidinger, G., Koprunner, M., Raz, E., 2002. Multiple levels of posttranscriptional control lead to germ line-specific gene expression in the zebrafish. Curr. Biol. 12, 289-294.

Wu, X., Wang, Z., Jiang, J., Gao, J., Wang, J., Zhou, X., Zhang, Q., 2014. Cloning, expression promoter analysis of vasa gene in Japanese flounder (Paralichthys olivaceus). Comp. Biochem. Physiol. B Biochem. Mol. Biol. 167, 41-50.

Xu, H., Gui, J., Hong, Y., 2005. Differential expression of vasa RNA and protein during spermatogenesis and oogenesis in the gibel carp (Carassius auratus gibelio), a bisexually and gynogenetically reproducing vertebrate. Dev. Dyn. 233, 872-882.

Xu, H., Lim, M., Dwarakanath, M., Hong, Y., 2014. Vasa identifies germ cells and critical stages of oogenesis in the Asian seabass. Int. J. Biol. Sci. 10, 225-235.

Yan, M., Sui, J., Sheng, W., Shao, M., Zhang, Z., 2013. Expression pattern of vasa in gonads of sea cucumber Apostichopus japonicus during gametogenesis and reproductive cycle. Gene Expr. Patterns 13, 171-176.

Yoon, C., Kawakami, K., Hopkins, N., 1997. Zebrafish vasa homologue RNA is localized to the cleavage planes of 2- and 4-cell-stage embryos and is expressed in the primordial germ cells. Development 124, 3157-3165.

Yoshizaki, G., Takeuchi, Y., Sakatani, S., Takeuchi, T., 2000. Germ cell-specific expression of green fluorescent protein in transgenic rainbow trout under control of the rainbow trout vasa-like gene promoter. Int. J. Dev. Biol. 44, 323-326.

Yuan, Y., Li, M., Hong, Y., 2014. Light and electron microscopic analyses of vasa expression in adult germ cells of the fish medaka. Gene 545, 15-22. 